\title{
Pubic Arch Angle Measurement by Transperineal Ultrasonography: A Prospective Cross-Sectional Study
}

\section{Medida do ângulo do arco púbico por ultrassonografia transperineal: um estudo prospectivo transversal}

\author{
Raimundo Homero Carvalho Neto ${ }^{10}$ Antonio Brazil Viana Junior ${ }^{1(}$ Antonio Fernandes Moron $^{2(1)}$ \\ Edward Araujo Júnior ${ }^{2,3}$ Francisco Herlânio Costa Carvalho ${ }^{10}$ Helvécio Neves Feitosa ${ }^{1,4}$ (1)
}

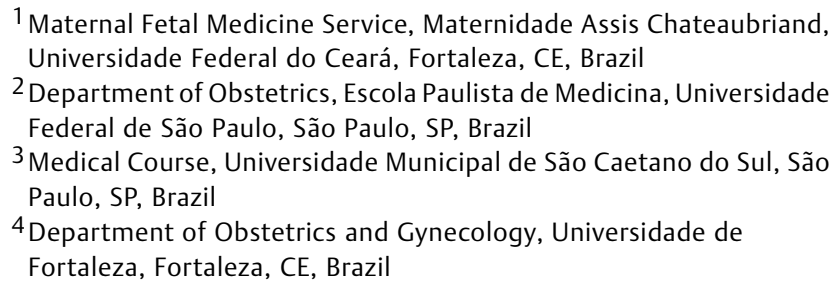

Address for correspondence Edward Araujo Júnior, PhD, Rua Botucatu, 740, 04023-062, Vila Clementino, São Paulo, SP, Brazil (e-mail: araujojred@terra.com.br).

Rev Bras Ginecol Obstet 2020;42(4):181-187.

\begin{abstract}
Keywords

- labor

- ultrasonography

- cephalopelvic disproportion

- vaginal delivery

- cesarean section

Resumo

Objective To evaluate the ability of the pubic arch angle (PAA) as measured by transperineal ultrasonography during labor to predict the delivery type and cephalic pole disengagement mode.

Methods The present prospective cross-sectional study included 221 women in singleton-gestational labor $\geq 37$ weeks with cephalic fetuses who underwent PAA measurement using transperineal ultrasonography. These measurements were correlated with the delivery type, cephalic pole disengagement mode, and fetal and maternal characteristics.

Results Out of the subjects, $153(69.2 \%)$ had spontaneous vaginal delivery, 7 (3.2\%) gave birth by forceps, and 61 (27.6\%) delivered by cesarean section. For the analysis, deliveries were divided into two groups: vaginal and surgical (forceps and cesarean). The mean PAA was $102 \pm 7.5^{\circ}$ (range, $79.3-117.7^{\circ}$ ). No statistically significant difference was observed in delivery type (102.6 $\pm 7.2^{\circ}$ versus $\left.100.8 \pm 7.9^{\circ}, p=0.105\right)$. The occipitoanterior position was seen in $94.1 \%$ of the fetuses and the occipitoposterior position in $5.8 \%$. A narrower PAA was found in the group of surgical deliveries $\left(97.9 \pm 9.6^{\circ}\right.$ versus $\left.102.6 \pm 7.3^{\circ}, p=0.049\right)$. Multivariate regression analysis showed that PAA was a predictive variable for the occurrence of head disengagement in occipital varieties after birth (odds ratio, 0.9; 95\% confidence interval, $0.82-0.99 ; p=0.026$ ).

Conclusion Ultrasonographic measurement of the PAA was not a predictor of delivery type, but was associated with the persistence of occipital varieties after birth.

Objetivo Avaliar a medida do ângulo do arco púbico (AAP) por ultrassonografia transperineal durante trabalho de parto em predizer tipo de parto e modo de desprendimento do polo cefálico.
\end{abstract}

received

November 14, 2018

accepted

March 9, 2020
DOI https://doi.org/ 10.1055/s-0040-1709690. ISSN 0100-7203.
Copyright $\odot 2020$ by Thieme Revinter

Publicações Ltda, Rio de Janeiro, Brazil
License terms

(c) (1) 


\author{
Palavras-chave \\ - trabalho de parto \\ - ultrassonografia \\ - desproporção \\ cefalo-pélvica \\ - parto vaginal \\ - cesárea
}

\begin{abstract}
Métodos Um estudo prospectivo transversal foi conduzido com 221 mulheres em trabalho de parto com gestação única $\geq 37$ semanas, com fetos em apresentação cefálica, foram submetidas à avaliação ultrassonográfica por via transperineal para aferição do AAP. Correlações com tipo de parto, modo de desprendimento do polo cefálico e características fetais e maternas foram realizadas.

Resultados Um total de 153 (69,2\%) mulheres apresentaram parto vaginal espontâneo, 7 (3,2\%) parto a fórceps e $61(27,6 \%)$ parto cesárea. Para fins de análise, dividiu-se os partos em dois grupos: partos vaginais e cirúrgicos (fórceps e cesáreas). A média do AAP foi $102 \pm 7,5^{\circ}$ (variação: 79,3-117,7²). Não foi observada significância estatística do AAP em relação ao tipo de parto $\left(102,6 \pm 7,2^{\circ}\right.$ versus $\left.100,8 \pm 7,9^{\circ} ; p=0,105\right)$. Um total de $94,1 \%$ dos fetos desprenderam em variedade de posição occipito anterior e $5,8 \%$ em occipito posterior. Encontrou-se AAP mais estreitado no grupo de partos cirúrgicos $\left(97,9 \pm 9,6^{\circ}\right.$ versus $\left.102,6 \pm 7,3^{\circ} ; p=0,049\right)$. A análise de regressão multivariada demonstrou que AAP foi uma variável de proteção para a ocorrência de desprendimento da cabeça em variedades occipito posteriores ao nascimento (odds ratio $[O R]=0,9$; índice de confiança (IC) 95\%: 0,82-0,99; $p=0,026$ ).

Conclusão A medida ultrassonográfica do AAP não foi preditora do tipo de parto, porém demonstrou associação com persistência de variedades occipito posteriores ao nascimento.
\end{abstract}

\section{Introduction}

A good proportion between the fetal head and maternal pelvis is a fundamental condition for the physiological presentation of childbirth. During its descent, the cephalic pole performs flexion, rotation, and extension and develops plastic alterations in its format. The birth canal also adaptsthat is, mobility of the sacrococcygeal joint increases and the soft tissues become distended. Such changes are necessary since the head diameters of a term fetus are similar to the main diameters of the pelvis, requiring the latter to adapt to the birth canal to enable the fetus to cross it. ${ }^{1}$

The disparity between pelvic architecture or size and the fetal head constitutes an obstetric entity called cephalopelvic disproportion (CPD), a cause of increased operative emergencies during delivery and adverse perinatal outcomes, accounting for $8 \%$ of all maternal deaths worldwide. ${ }^{2}$ Cephalopelvic disproportion is diagnosed during labor, and its prediction at the end of gestation or onset of labor improves fetal outcomes and avoids stress and dissatisfaction in pregnant women due to prolonged labor that ultimately results in emergency cesarean section. $^{3}$

Pelvimetry, a method that studies pelvic shape and proportions, can be performed clinically through the measurement of the diagonal conjugate, interischial distance, and bituberous diameter ${ }^{1}$ or using imaging methods such as radiography, computed tomography (CT), magnetic resonance imaging (MRI), and ultrasonography. ${ }^{4,5}$ The accuracy of the clinical detection of pelvic narrowing is limited to $50 \%{ }^{6}$ The use of X-rays not only causes exposure to ionizing radiation, but also doubles the incidence of abdominal births. ${ }^{7}$ Computed tomography and MRI are effective but very costly and often impractical within an obstetric center.
Ultrasonography is highly accessible in delivery rooms, has a smaller learning curve, is painless, is easy to perform, and is relatively innocuous. For these reasons, it has become a widely used method. ${ }^{8-12}$ The main parameter studied on ultrasonography in such cases is the pubic arch angle (PAA), which is formed by the confluence of the pubic bone rami at the level of the symphysis. ${ }^{13}$ This angle provides indirect information about pelvic shape and obstetric dimensions such as the superior aperture of the pelvis and the interspinous distance. ${ }^{14}$ The gynecoid pelvis has a wide PAA and favors rotation of the cephalic pole to the occipitoanterior position. In women with a narrow anterior pelvic compartment in which the PAA is decreased, as in android pelvis, the pubic rami converge at a sharper angle. In these situations, the fetal head tends to position itself in the posterior compartment of the birth canal, being forced against the soft tissues and bony structures in this region. This impairs the rotation of the occiput to the anterior positions, increasing the frequency of transversal and persistent posterior varieties and leading to the occurrence of dystocia and surgical delivery. ${ }^{15-17}$

Several studies have evaluated the efficacy of the PAA measurement, both before and during labor, at predicting the delivery route and cephalic pole detachment mode. ${ }^{13,17}$ These studies examined specific population groups from Europe, the Middle East, and Oceania. However, evaluations in other populations with different anthropometric characteristics are required to corroborate the applicability of this method and increase its acceptability; notably in the Brazilian population that presents anthropometric heterogeneity due to its racial mixture.

The objective of the present study was to analyze whether the PAA measure, as a parameter of pelvic proportion, is able 
to predict the delivery type and cephalic pole disengagement mode.

\section{Methods}

The present prospective cross-sectional study was conducted between February and September 2017 at the Assis Chateaubriand Teaching Maternity of the Universidade Federal do Ceará (UFC), Fortaleza, state of Ceará, Brazil. A convenience sample of 221 parturients was recruited in the first or second phase of labor according to the clinical evolution at admission. Transperineal ultrasonography was used to measure the PAA (exposure variable); these data were compared with delivery type (vaginal and surgical) and cephalic pole disengagement mode (occipitoanterior or occipitoposterior, variables of outcome) in search of associations. The sum of the forceps and cesarean deliveries was considered surgical delivery. Other relevant information possibly capable of predicting delivery type and cephalic pole disengagement mode or of distorting the associations described above was also studied. This included maternal age, maternal height, body mass index (BMI), parity, birthweight, type of labor onset (spontaneous or induced), labor analgesia, and use of uterotonic agents. Gestational age was not compared because all patients in the study were full term ( $\geq 37$ weeks). Informed consent was obtained from all patients, and the present study was approved by the UFC Research Ethics Committee under the opinion number 1.010.040.

The inclusion criterion was a singleton pregnancy with a live fetus without structural anomalies in cephalic presentation with estimated fetal weight by ultrasound considered adequate for gestational age and biparietal diameter $<2$ standard deviations (SDs) for gestational age; regardless of whether the amniotic sac was intact or broken or whether the patients received labor analgesia. Patients were excluded if on admission they presented urgent situations requiring immediate pregnancy resolution by cesarean section, such as: uterine rupture, umbilical cord prolapse, placental abruption with changes in fetal auscultation, and cardiotocographic tracings classified in category 3 of the National Institute of Child Health and Human Development 2008. ${ }^{18}$ Also, newborns with $\geq 4,000 \mathrm{~g}$ were excluded.

Pubic arch angle measurement was performed by a single examiner (Carvalho R. H.) using a Logic C5 Premium ultrasound device (General Electric, Milwaukee, WI, USA) equipped with a two-dimensional (3-5 MHz) convex transducer. The PAA measurements were obtained transperineally, outside the period of contraction or pull, with the women in the dorsal decubitus position and the legs ajar and semi-flexed.

The probe was positioned transversally in contact with the perineum at the level of the clitoris. The transducer was tilted at $\sim 45^{\circ}$ until an image of the symphysis with the 2 branches of the pubic bone in symmetrical position was obtained. The lines for angle measurement were positioned on the lower edges of the right and left pubic branches, forming a triangle based on the ischial tuberosities bilaterally and on the convergence at the center of the symphysis as the apex (-Fig. 1), as previously described by Gilboa et al. ${ }^{13}$ Three PAA measurements were obtained from each participant, and the average of the three measurements was considered.

Ultrasound findings were not revealed to the members of the obstetrical staff to avoid interference with labor. The follow-up of the delivery was the responsibility of the on-call care team, which followed the routine recommended by institutional protocols. $^{19}$

The descriptive data are presented as mean \pm SD or $n(\%)$. The Chi-squared and Fisher exact tests were used to analyze the categorical variables, and the Mann-Whitney or Student $t$-test test was used to analyze continuous variables according to the normality of the data. The analyzed variables were PAA; patient age, height, body mass index (BMI), and parity; birth weight; labor onset type (spontaneous or induced); labor analgesia; and the use of uterotonic agents according to
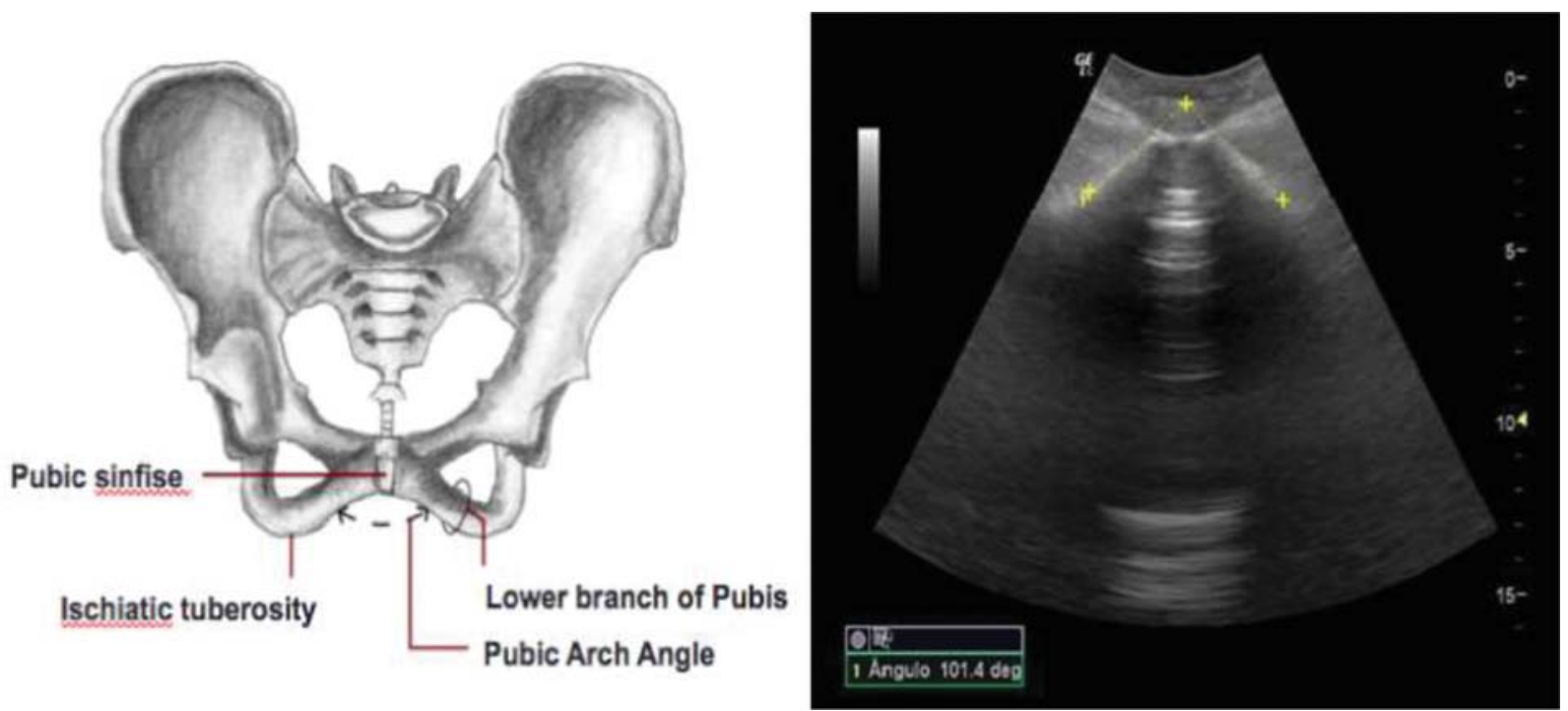

Fig. 1 Schematic drawing of the pubic arch angle (PAA) (left) and PAA image obtained by transperineal ultrasonography during the first phase of delivery (right). 
delivery type (vaginal or surgical) and cephalic pole disengagement mode (occipitoanterior or occipitoposterior) as the outcome variables.

All variables presenting a value of $p<0.20$ for one or both outcomes were subjected to multiple logistic regression analysis for both outcomes (surgical delivery and cephalic pole disengagement in the occipitoposterior position). Values of $p<0.05$ were considered statistically significant. The gross odds ratio (OR) was calculated and adjusted with its respective $95 \%$ confidence interval $(\mathrm{CI})$. The data were analyzed by SPSS for Windows, version 13.0 (SPSS, Inc., Chicago, IL, USA).

\section{Results}

The clinical and obstetric characteristics of the 221 participants as well as the birth and outcome details are shown in - Table 1.

Table 1 Characteristics of the study population, deliveries, and outcomes

\begin{tabular}{|c|c|c|}
\hline Variable & Mean \pm SD & $n(\%)$ \\
\hline Maternal age (years old) & $24.2 \pm 6.8$ & - \\
\hline \multicolumn{3}{|l|}{ Parity } \\
\hline 0 & - & $129(58.4)$ \\
\hline 1 & - & $63(28.5)$ \\
\hline 2 & - & $19(8.6)$ \\
\hline 3 & - & $7(3.2)$ \\
\hline 4 & - & $1(0.5)$ \\
\hline 5 & - & $1(0.5)$ \\
\hline 9 & - & $1(0.5)$ \\
\hline Maternal height (m) & $1.57 \pm 0.6$ & - \\
\hline Maternal weight (kg) & $72.4 \pm 14$ & - \\
\hline BMI $\left(\mathrm{kg} / \mathrm{m}^{2}\right)$ & $29.3 \pm 4.7$ & - \\
\hline Gestational age (US) (weeks) & $39.4 \pm 1.1$ & - \\
\hline Birth weight $(g)$ & $3.312 .1 \pm 427$ & - \\
\hline Labor analgesia & - & $32(14.5)$ \\
\hline Use of uterotonic agents & - & $78(36.1)$ \\
\hline Previous cesarean section & - & $16(7.2)$ \\
\hline Labor induction & - & $16(7.3)$ \\
\hline \multicolumn{3}{|l|}{ Delivery type } \\
\hline Spontaneous vaginal & - & $153(69.2)$ \\
\hline Forceps & - & $7(3.2)$ \\
\hline Cesarean section & - & $61(27.6)$ \\
\hline \multicolumn{3}{|l|}{ Cephalic pole disengagement } \\
\hline Occipitoanterior & - & $161(94.2)$ \\
\hline Occipitoposterior & - & $10(5.8)$ \\
\hline
\end{tabular}

Abbreviations: BMI, body mass index; SD, standard deviation; US, ultrasonography.
There were 153 (69.2\%) vaginal deliveries, 7 (3.2\%) forceps deliveries, and 61 (27.6\%) cesarean deliveries. -Table 2 shows the univariate analysis results stratified according to delivery type (vaginal versus surgical). Surgical delivery was associated with shorter maternal height $(1.58 \pm 0.06 \mathrm{~m}$ versus $1.55 \pm 0.06 \mathrm{~m} ; p<0.001)$, higher BMI $(28.6 \pm 4.6$ $\mathrm{kg} / \mathrm{m}^{2}$ versus $\left.30.8 \pm 4.7 \mathrm{~kg} / \mathrm{m}^{2} ; p<0.001\right)$, greater use of labor analgesia $(15 / 153$ or $9.9 \%$ versus $17 / 68$ or $17 \%$; $p<0.003$ ), and lower parity $(78 / 153$ or $51 \%$ versus $51 / 68$ or $75 \% ; p<0.001)$. No statistically significant difference was observed for PAA among delivery types $\left(102.6 \pm 7.20^{\circ}\right.$ versus $\left.100.8 \pm 7.90^{\circ} ; p=0.105\right)$.

- Table 3 shows the stratification of the data by fetal occiput position on disengagement. In 171/221 study patients, it was possible to retrieve this information from the medical records. An association was noted between the use of labor analgesia and the occurrence of disengagement in the occipital position at birth (20/161 or $12.2 \%$ versus $4 / 10$ or $40 \% ; p=0.013$ ). Pubic arch angle regarding fetal occiput position on disengagement differed significantly. Narrower angles were associated with occipitoposterior positions $\left(102.6 \pm 7.30^{\circ}\right.$ versus $\left.97.9 \pm 9.60^{\circ} ; p=0.049\right)$.

The results of the multivariate regression model of variables with $p$ values $<0.20$ are shown in - Tables 4 and $\mathbf{5}$. In the analysis of the surgical delivery type outcome ( - Table 4 ), 4 variables were relevant, representing a risk for this type of resolution: maternal height $<1.57 \mathrm{~m}$ (OR: 3.05; 95\%CI: 1.55-6.02; $p=0.001$ ); BMI/obesity (OR: 3.89; 95\%CI: $1.38--$ $10.93 ; p=0.010$ ); nulliparity (OR: $2.89 ; 95 \% \mathrm{CI}: 1.42-5.87$; $p=0.003$ ), and use of labor analgesia (OR: $2.68 ; 95 \% \mathrm{CI}$ : $1.08-6.68 ; p=0.034)$. When analyzing the outcome variable of cephalic pole disengagement in the posterior positions

Table 2 Population characteristics stratified by delivery type

\begin{tabular}{|c|c|c|c|}
\hline & $\begin{array}{l}\text { Vaginal } \\
(n=153)\end{array}$ & $\begin{array}{l}\text { Surgical } \\
\text { (forceps and } \\
\text { cesarean } \\
\text { section) } \\
(n=68)\end{array}$ & p-value \\
\hline Age (years old) & $24.0 \pm 6.91$ & $24.57 \pm 6.66$ & $0.588^{\mathrm{a}}$ \\
\hline Height (m) & $1.58 \pm 0.06$ & $1.55 \pm 0.06$ & $<0.001^{\mathrm{a}}$ \\
\hline BMI $\left(\mathrm{kg} / \mathrm{m}^{2}\right)$ & $28.6 \pm 4.55$ & $30.82 \pm 4.73$ & $0.001^{\mathrm{a}}$ \\
\hline Parity & & & $0.001^{\mathrm{b}}$ \\
\hline Nulliparous & $78(51 \%)$ & $51(75 \%)$ & \\
\hline Multiparous & 75 (49\%) & $17(25 \%)$ & \\
\hline Labor analgesia & $15(9.9 \%)$ & $17(25 \%)$ & $<0.003^{b}$ \\
\hline Delivery type & & & $0.622^{\mathrm{b}}$ \\
\hline Spontaneous & $141(92.2 \%)$ & $63(94 \%)$ & \\
\hline Induced & $12(7.8 \%)$ & $4(6 \%)$ & \\
\hline Use of uterotonic agent & $s 48(32.2 \%)$ & $30(44.8 \%)$ & $0.075^{\mathrm{b}}$ \\
\hline Birth weight $(g)$ & \multicolumn{3}{|c|}{$3287.9 \pm 429.83366 .4 \pm 418.840 .208^{a}$} \\
\hline Pubic arc angle $\left({ }^{\circ}\right)$ & $102.56 \pm 7.22$ & $100.8 \pm 7.96$ & $0.105^{\mathrm{a}}$ \\
\hline
\end{tabular}

Abbreviation: BMI, body mass index.

astudent $t$-test.

${ }^{\mathrm{b}}$ Chi-squared test. 
Table 3 Population characteristics stratified by fetal occiput position on disengagement

\begin{tabular}{|c|c|c|c|}
\hline Variable & $\begin{array}{l}\text { Occipitoanterior } \\
(n=161)\end{array}$ & $\begin{array}{l}\text { Occipitoposterior } \\
(n=10)\end{array}$ & $p$-value \\
\hline Age (years old) & $24.17 \pm 6.71$ & $22 \pm 7.24$ & $0.324^{\mathrm{a}}$ \\
\hline Height (m) & $1.58 \pm 0.06$ & $1.58 \pm 0.05$ & $0.647^{a}$ \\
\hline BMI $\left(\mathrm{kg} / \mathrm{m}^{2}\right)$ & $28.95 \pm 4.61$ & $27.8 \pm 3.54$ & $0.444^{\mathrm{a}}$ \\
\hline Parity & & & $0.271^{\mathrm{b}}$ \\
\hline Nulliparous & $86(52.1 \%)$ & 7 (70\%) & \\
\hline Multiparous & 79 (47.9\%) & $3(30 \%)$ & \\
\hline Labor analgesia & $20(12.2 \%)$ & $4(40 \%)$ & $0.013^{b}$ \\
\hline Delivery type & & & $0.670^{\mathrm{b}}$ \\
\hline Spontaneous & $153(92.7 \%)$ & $8(88.9 \%)$ & \\
\hline Induced & $12(7.3 \%)$ & $1(11.1 \%)$ & \\
\hline $\begin{array}{l}\text { Use of uterotonic } \\
\text { agents }\end{array}$ & $53(32.9 \%)$ & $6(60 \%)$ & $0.080^{\mathrm{b}}$ \\
\hline Birthweight (g) & $3310.38 \pm 430.27$ & $3088 \pm 296.41$ & $0.109^{a}$ \\
\hline Pubic arc angle $\left({ }^{\circ}\right)$ & $102.58 \pm 7.27$ & $97.92 \pm 9.59$ & $0.049^{a}$ \\
\hline
\end{tabular}

Abbreviation: BMI, body mass index.

${ }^{\mathrm{a}}$ Student $t$-test.

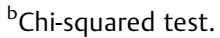

(-Table 5), labor analgesia did not differ significantly, unlike the PAA, which showed an association as a protection factor for this occurrence (OR: $0.90 ; 95 \% \mathrm{CI}$ : $0.82-0.99 ; p=0.026$ ). The PAA showed a negative correlation with fetal head disengagement at the occipitoposterior position - that is, each degree of PAA decrease caused an $11 \%$ increase in the risk of delivery with the cephalic pole at the posterior occipitoposition.

\section{Discussion}

Most groups that use intrapartum ultrasound in centers in Europe, the Middle East, Asia, and North America apply three-dimensional (3D) technology. ${ }^{13,15,17,20}$ In the present study, two-dimensional (2D) ultrasonography was used since it is the method available in most maternity hospitals in Brazil and is less costly and easier to perform. Torkildsen et $\mathrm{al}^{21}$ found good intraobserver agreement and reproducibility between 2D and 3D techniques. Corroborating this finding, the results of the present study were close to those found in studies that used 2D technology, with a mean PAA of $102.0 \pm 7.5^{\circ}$. Using 2D ultrasonography, Gilboa et $\mathrm{al}^{13}$ found a mean PAA of $101.1 \pm 13.1^{\circ}$ in a cohort of 62 Israeli women in the prolonged second stage of labor. Applying 3D technology, Albrich et $\mathrm{al}^{20}$ found a mean PAA of $109.3 \pm 8.9^{\circ}$ in a cohort of 611 Australian women at between 34 and 36 weeks of gestation.

Our study results demonstrate that maternal height, BMI, and epidural analgesia influence delivery type. Surgical delivery occurred more frequently in shorter or obese women as well as in those who used labor analgesia, corroborating findings in the literature, which demonstrated an increase in the incidence of surgical delivery with short maternal height and obesity ${ }^{22,23}$ as well as higher occurrences of instrumental deliveries in patients receiving epidural analgesia. ${ }^{24}$

The PAA was not a predictor of delivery type as in other studies, which also failed to demonstrate this association. ${ }^{20,25}$ However, contrary results were obtained by Gilboa et $\mathrm{al}^{13}$ and Ghi et $\mathrm{al}^{17}$ who observed that women with surgical delivery outcomes had smaller PAAs than those who had vaginal delivery $\left(97.1 \pm 11.5^{\circ}\right.$ versus $110.1 \pm 14.0^{\circ}$ and $111.4 \pm 13.5^{\circ}$ versus $118.4 \pm 11.4^{\circ}$, respectively). It should be considered that, unlike in the current study, the population evaluated in those studies consisted only of pregnant women in the second phase of labor; ${ }^{13,17}$ in one, all patients selected presented progression failure at this stage. ${ }^{13}$ Some factors should be considered in the evaluation of these conflicting results, such as different study designs, various pelvic conformations, and various delivery modes and different rates of uterotonic agent use and analgesia that affect the local incidence of cesarean section and interfere with the study findings.

Table 4 Logistic regression analysis results of surgical delivery outcome

\begin{tabular}{|c|c|c|c|c|c|c|}
\hline \multirow[t]{2}{*}{ Variable } & \multicolumn{3}{|c|}{ Univariate } & \multicolumn{3}{|c|}{ Multivariate } \\
\hline & B & OR $(95 \% \mathrm{Cl})$ & p-value & B & OR $(95 \% \mathrm{Cl})$ & p-value \\
\hline Height $<1.57$ m & 0.95 & $2.58(1.41-4.73)$ & 0.002 & 1.12 & $3.05(1.55-6.02)$ & 0.001 \\
\hline \multicolumn{7}{|l|}{ BMI $\left(\mathrm{kg} / \mathrm{m}^{2}\right)$} \\
\hline Adequate & & reference & & & & \\
\hline Overweight & 0.87 & $2.38(1.03-7.293)$ & 0.043 & 0.90 & $2.47(0.87-6.97)$ & 0.089 \\
\hline Obese & 0.34 & $3.62(1.39-9.46)$ & 0.009 & 1.36 & $3.89(1.38-10.93)$ & 0.010 \\
\hline Nulliparous & 1.06 & $2.89(1.53-5.44)$ & 0.001 & 1.06 & $2.89(1.42-5.87)$ & 0.003 \\
\hline Labor analgesia & 1.11 & $3.04(1.42-6.54)$ & 0.004 & 0.99 & $2.68(1.08-6.68)$ & 0.034 \\
\hline Use of uterotonic agents & 0.53 & $1.71(0.94-3.08)$ & 0.007 & 0.21 & $1.22(0.60-2.51)$ & 0.574 \\
\hline Birth weight $>3,325 \mathrm{~g}$ & 0.27 & $1.31(0.74-2.32)$ & 0.358 & 0.40 & $1.5(0.77-2.92)$ & 0.236 \\
\hline Pubic arc angle $\left(^{\circ}\right)$ & -0.03 & $0.97(0.93-1.01)$ & 0.106 & -0.04 & $0.97(0.92-1.01)$ & 0.116 \\
\hline
\end{tabular}

$\mathrm{B}$, variable coefficient in the regression model; $\mathrm{BMI}$, body mass index; $\mathrm{Cl}$, confidence interval; OR, odds ratio.

$\mathrm{R}^{2}$ Nagelkerke = 0.24; Median height, $1.57 \mathrm{~m}$ (1.54-1.1 m); Median birthweight, 3,325 g (2,995-3,615 g). 
Table 5 Logistic regression analysis results of fetal head disengagement (occipitoposterior) outcome

\begin{tabular}{lllllll}
\hline Variable & Univariate & \multicolumn{3}{l}{ Multivariate } \\
\hline & B & OR $(95 \% \mathrm{Cl})$ & -value & B & OR (95\%Cl) & $p$-value \\
\hline Height $<1.57 \mathrm{~m}$ & 0.04 & $1.04(0.29-3.72)$ & 0.955 & -0.08 & $0.92(0.22-3.86)$ & 0.913 \\
BMI $\left(\mathrm{kg} / \mathrm{m}^{2}\right)$ & & & & & & \\
Adequate & & reference & & & & \\
$\quad$ Overweight & 0.11 & $1.11(0.26-4.72)$ & 0.886 & 0.23 & $1.25(0.25-6.19)$ & 0.782 \\
$\quad$ Obese & -1.75 & $0.17(0.02-1.74)$ & 0.136 & -2.01 & $0.13(0.01-1.56)$ & 0.108 \\
Nulliparous & 0.76 & $2.14(0.54-8.58)$ & 0.281 & 0.28 & $1.32(0.26-6.80)$ & 0.737 \\
Labor analgesia & 1.57 & $4.8(1.25-18.49)$ & 0.023 & 1.08 & $2.96(0.56-15.71)$ & 0.203 \\
Use of uterotonic agents & 0.53 & $1.71(0.94-3.08)$ & 0.094 & 0.79 & $2.20(0.46-10.43)$ & 0.320 \\
Birth weight $>3325 \mathrm{~g}$ & -1.37 & $0.25(0.05-1.23)$ & 0.088 & -1.45 & $0.24(0.04-1.50)$ & 0.126 \\
Pubic arc angle $\left(^{\circ}\right)$ & -0.08 & $0.93(0.86-1)$ & 0.060 & -0.11 & $0.90(0.82-0.99)$ & 0.026 \\
\hline
\end{tabular}

$\mathrm{B}$, variable coefficient in the regression model; $\mathrm{BMI}$, body mass index; $\mathrm{Cl}$, confidence interval; $\mathrm{OR}$, odds ratio.

$\mathrm{R}^{2}$ Nagelkerke = 0.274; Median height, $1.57 \mathrm{~m}$ (1.54-1.1 m); Median birth weight, 3,325 g $(2,995-3,615 \mathrm{~m})$.

Considering the fetal head disengagement outcome variable, the PAA was associated with the occurrence of occipitoposterior varieties. Smaller PAAs were observed in patients who delivered fetuses in the occipitoposterior position than in the anterior positions. Ghi et $\mathrm{a} \mathrm{l}^{17}$ also found an association between PAA narrowing and the occipitoposterior variety at delivery (OR: 1.04; 95\%CI: $1.01-1.08$ ). These results demonstrated a lower PAA in patients who gave birth to fetuses with heads in posterior varieties than in those whose fetuses were delivered in anterior positions $\left(104.3 \pm 16.8^{\circ}\right.$ versus $\left.116.4 \pm 11.9^{\circ}\right) .{ }^{17}$ The findings of these two studies reinforce a recent hypothesis in the literature that assumes that the occurrence of persistent occipitoposterior varieties in labor may be an adaptive phenomenon to narrowing of the anterior pelvic compartment. ${ }^{15}$ When the care team is aware that the parturient has a reduced PAA, this provides guidance on a likely prolongation of labor in addition to favoring a more attentive attitude regarding the possibility of dystocia as well as the possible need for an instrumental delivery and an episiotomy.

Regarding the limitations of the present study, it is possible that the low socioeconomic level of the studied population impacted the different types of childbirth. The preference for cesarean section influenced by sociocultural factors ${ }^{26}$ was associated with the low use of instrumental delivery and the nonuse of manual head rotation in the facility where the present study was performed, resulting in an increased incidence of cesarean section, and may have interfered with the attempt to demonstrate the association of the PAA with delivery type. No other methods, such as CT or MRI, were used to validate the ultrasound measurements. The incomplete medical records caused gaps that made it difficult to analyze some of the data more substantially, such as the duration of the second phase of labor that was cited by Gilboa et a ${ }^{13}$ as inversely proportional to the measurement of the PAA. Another limitation to be considered is that the present study did not intend to apply 3D ultrasound or other $2 \mathrm{D}$ ultrasound parameters to assess mater- nal pelvis or fetal head malposition (deflection and asynclitism) that contribute to the occurrence of dystocia. ${ }^{27}$

New studies are required to clarify the discordant results in the literature regarding the influence of PAA on the evolution of labor. However, the importance of this knowledge for better delivery assistance is well understood at our institution; due to the good sampling and technical rigor used, these data can be extrapolated to parturients similar to those included in the present study.

\section{Conclusion}

In summary, the ultrasound measurement of the PAA was not a predictor of delivery type but was associated with the persistence of occipitoposterior varieties in fetal head disengagement.

\section{Contributors}

All of the authors contributed with the project and data interpretation, the writing of the article, the critical review of the intellectual content, and with the final approval of the version to be published.

\section{Conflict of Interests}

The authors have no conflict of interests to declare.

\section{References}

1 Neal JL, Lowe NK, Caughey AB, Bennet KA, Tilden EL, Carlson NS, et al. Applying a physiologic partograph to Consortium on Safe Labor data to identify opportunities for safely decreasing cesarean births among nulliparous women. Birth. 2018;45(04):358-367. Doi: $10.1111 /$ birt.12358

2 Filippi V, Chou D, Ronsmans C, Graham W, Say L. Levels and causes of maternal mortality and morbidity. In: Black RE, Laxminarayan $\mathrm{R}$, Temmerman $\mathrm{M}$, Walker $\mathrm{N}$, eds. Reproductive, maternal, newborn, and child health: disease control priorities. 3rd ed. Washington (DC): The International Bank for Reconstruction and Development/The World Bank; 2016. vol. 2, p. 51-70 
3 Yeo L, Romero R. Sonographic evaluation in the second stage of labor to improve the assessment of labor progress and its outcome. Ultrasound Obstet Gynecol. 2009;33(03):253-258. Doi: 10.1002/uog.6336

4 Suramo I, Torniainen P, Jouppila P, Kirkinen P, Lähde S. A low-dose CT-pelvimetry. Br J Radiol. 1984;57(673):35-37. Doi: 10.1259/00071285-57-673-35

5 Spörri S, Hänggi W, Braghetti A, Vock P, Schneider H. Pelvimetry by magnetic resonance imaging as a diagnostic tool to evaluate dystocia. Obstet Gynecol. 1997;89(06):902-908. Doi: 10.1016/ s0029-7844(97)00148-8

6 Dudding TC, Vaizey CJ, Kamm MA. Obstetric anal sphincter injury: incidence, risk factors, and management. Ann Surg. 2008;247 (02):224-237. Doi: 10.1097/SLA.0b013e318142cdf4

7 Pattinson RC. Pelvimetry for fetal cephalic presentations at term. Cochrane Database Syst Rev. 2000;(02):CD000161. Doi: 10.1002/14651858.CD000161

8 Sherer DM, Miodovnik M, Bradley KS, Langer O. Intrapartum fetal head position II: comparison between transvaginal digital examination and transabdominal ultrasound assessment during the second stage of labor. Ultrasound Obstet Gynecol. 2002;19(03):264-268. Doi: 10.1046/j.1469-0705.2002.00656.x

9 Akmal S, Kametas N, Tsoi E, Hargreaves C, Nicolaides KH. Comparison of transvaginal digital examination with intrapartum sonography to determine fetal head position before instrumental delivery. Ultrasound Obstet Gynecol. 2003;21(05):437-440. Doi: 10.1002/uog.103

10 Chou MR, Kreiser D, Taslimi MM, Druzin ML, El-Sayed YY. Vaginal versus ultrasound examination of fetal occiput position during the second stage of labor. Am J Obstet Gynecol. 2004;191(02): 521-524. Doi: 10.1016/j.ajog.2004.01.029

11 Rozenberg P, Porcher R, Salomon LJ, Boirot F, Morin C, Ville Y. Comparison of the learning curves of digital examination and transabdominal sonography for the determination of fetal head position during labor. Ultrasound Obstet Gynecol. 2008;31(03): 332-337. Doi: 10.1002/uog.5267

12 Barbera AF, Pombar X, Perugino G, Lezotte DC, Hobbins JC. A new method to assess fetal head descent in labor with transperineal ultrasound. Ultrasound Obstet Gynecol. 2009;33(03):313-319. Doi: 10.1002/uog.6329

13 Gilboa Y, Kivilevitch Z, Spira M, Kedem A, Katorza E, Moran O, Achiron R. Pubic arch angle in prolonged second stage of labor: clinical significance. Ultrasound Obstet Gynecol. 2013;41(04): 442-446. Doi: 10.1002/uog.12304

14 Yeomans ER. Clinical pelvimetry. Clin Obstet Gynecol. 2006;49 (01):140-146. Doi: 10.1097/01.grf.0000198185.94413.0d

15 Benavides L, Wu JM, Hundley AF, Ivester TS, Visco AG. The impact of occiput posterior fetal head position on the risk of anal sphincter injury in forceps-assisted vaginal deliveries. Am J Obstet Gynecol. 2005;192(05):1702-1706. Doi: 10.1016/j.ajog.2004.11.047
16 Caughey AB, Sharshiner R, Cheng YW. Fetal malposition: impact and management. Clin Obstet Gynecol. 2015;58(02):241-245. Doi: 10.1097/GRF.0000000000000106

17 Ghi T, Youssef A, Martelli F, Bellussi F, Aiello E, Pilu G, et al. Narrow subpubic arch angle is associated with higher risk of persistent occiput posterior position at delivery. Ultrasound Obstet Gynecol. 2016;48(04):511-515. Doi: 10.1002/uog.15808

18 Macones GA, Hankins GDV, Spong CY, Hauth J, Moore T. The 2008 National Institute of Child Health and Human Development workshop report on electronic fetal monitoring: update on definitions, interpretation, and research guidelines. Obstet Gynecol. 2008;112(03):661-666. Doi: 10.1097/AOG.0b013e3181841395

19 Universidade Federal do Ceará. Maternidade Escola Assis Chateaubriand. Protocolos e diretrizes terapêuticas: Unidade 6obstetrícia [Internet]. 2017 [cited 2018 Jan 05]. Available from: http://www.ebserh.gov.br/web/meac-ufc/protocolos-e-pops

20 Albrich SB, Shek K, Krahn U, Dietz HP. Measurement of subpubic arch angle by three-dimensional transperineal ultrasound and impact on vaginal delivery. Ultrasound Obstet Gynecol. 2015;46 (04):496-500. Doi: 10.1002/uog.14814

21 Torkildsen EA, Salvesen KÅ, Eggebø TM. Agreement between twoand three-dimensional transperineal ultrasound methods in assessing fetal head descent in the first stage of labor. Ultrasound Obstet Gynecol. 2012;39(03):310-315. Doi: 10.1002/uog.9065

22 Toh-Adam R, Srisupundit K, Tongsong T. Short stature as an independent risk factor for cephalopelvic disproportion in a country of relatively small-sized mothers. Arch Gynecol Obstet. 2012;285(06):1513-1516. Doi: 10.1007/s00404-011-2168-3

23 Burke N, Burke G, Breathnach F, McAuliffe F, Morrison JJ, Turner M, et al; Perinatal Ireland Research Consortium. Prediction of cesarean delivery in the term nulliparous woman: results from the prospective, multicenter Genesis study. Am J Obstet Gynecol. 2017;216(06):598.e1-598.e11. Doi: 10.1016/j.ajog.2017.02.017

24 Anim-Somuah M, Smyth RM, Jones L. Epidural versus non-epidural or no analgesia in labour. Cochrane Database Syst Rev. 2011; (12):CD000331. Doi: 10.1002/14651858.CD000331.pub3

25 Albrich S, Laterza RM, Merinsky A, Skala C, Koelbl H, Naumann G. [Measurement of the infrapubic angle using 3D perineal ultrasound and its relationship to obstetrical parameters]. Ultraschall Med. 2012;33(07):E95-E100. Doi: 10.1055/s-0031-1299053

26 Leão MRC, Riesco MLG, Schneck CA, Angelo M. [Reflections on the excessive rates of cesareans in Brazil and the empowerment of women]. Cien Saude Colet. 2013;18(08):2395-2400. Doi: 10.1590/s1413-81232013000800024

27 Bellussi F, Ghi T, Youssef A, Ginevra Salsi, Francesca Giorgetta, Parma Dila, et al. The use of intrapartum ultrasound to diagnose malpositions and cephalic malpresentations. Am J Obstet Gynecol. 2017;217(06):633-641. Doi: 10.1016/j.ajog.2017.07.025 